\title{
Non-genomic thyroid hormone signaling through NO/cGMP/PKGII
}

\author{
Hema Kalyanaraman', Raphaela Schwappacher', Jisha Joshua', Shunhui Zhuang ${ }^{1}$, Brian Scott', \\ Wolfgang Dillmann', John Frangos ${ }^{2}$, Renate B Pilz ${ }^{1 *}$ \\ From 6th International Conference on cGMP: Generators, Effectors and Therapeutic Implications \\ Erfurt, Germany. 28-30 June 2013
}

\section{Background}

Skeletal integrity requires continuous bone remodelling by osteoblasts and osteoclasts, and thyroid hormone $(\mathrm{TH})$ is a key regulator of bone remodelling. Excess TH (hyperthyroidism) causes net bone loss, resulting in osteoporosis and increased fracture risk; lack of TH (hypothyroidism) also increases fracture risk because bones become brittle from decreased bone turnover [1]. TH stimulates bone formation and resorption through processes that are only partly defined; it enhances osteoblast proliferation and differentiation, and induces osteoblast production of the osteoclast differentiation factor RANKL (receptor activator of nuclear factor $-\kappa \mathrm{B}$ ligand). Nuclear TH receptors (THR- $\alpha$ and THR- $\beta$ ) act as transcriptional regulators and generate the hormone's classic "genomic" effects [1]. In different cell types, $\mathrm{TH}$ also has transcription-independent ("non-genomic") effects, including stimulation of the MEK/Erk and PI3K/Akt/mTOR kinase cascades, but the molecular mechanisms mediating these non-genomic effects are largely unknown.

\section{Results}

We found that physiological concentrations of 3,5,3'triiodo-L-thyronine $\left(\mathrm{T} 3,10^{-9}\right.$ to $\left.10^{-11} \mathrm{M}\right)$, but not reverseT3, rapidly increase NO production, and activate Src, Erk, and Akt in osteoblasts. These TH effects required THR- $\alpha$, but were independent of THR $-\beta$. We identified a novel, membrane-bound THR- $\alpha$ isoform that mediates T3-induced Erk/Akt activation, but does not affect transcription from $\mathrm{TH}$ response element-containing promoters. Signalling via the newly-discovered THR- $\alpha$ isoform was blocked by inhibitors of NO synthase, guanylate

\footnotetext{
* Correspondence: rpilz@ucsd.edu

'Department of Medicine and Moores Cancer Center, University of California, San Diego, La Jolla, California 92093-0652, USA

Full list of author information is available at the end of the article
}

cyclase (sGC), or protein kinase $\mathrm{G}$ (PKG), and was defective in endothelial NO synthase (eNOS)- or PKG II-deficient osteoblasts. We showed previously that NO/cGMP induce osteoblast proliferation through PKG II activation of Src and Erk, and established a mechanism for Src activation by PKG II [2]. We now show that TH enhances osteoblast proliferation and survival, and induces osteocalcin and fos family gene expression in a NO/cGMP/ PKG-dependent fashion via "non-genomic" activation of Erk. In contrast, TH-induced expression of the osteoclast regulator RANKL occurs independently of $\mathrm{NO}$, suggesting a classic "genomic" effect via nuclear THR- $\alpha$. Consistent with these results, treatment with the sGC activator cinaciguat increased bone formation in hypothyroid mice, without affecting osteoclast numbers.

\section{Conclusion}

We conclude that anabolic effects of $\mathrm{TH}$ in osteoblasts are mediated predominantly by non-genomic TH signalling, via activation of a novel, membrane-bound THR- $\alpha$ isoform, with subsequent activation of eNOS, sGC, PKGII, Src, Erk, and Akt. Our results are consistent with the phenotype of THR- $\alpha$ knockout mice and the role of NO in bone biology.

\footnotetext{
Authors' details

'Department of Medicine and Moores Cancer Center, University of California, San Diego, La Jolla, California 92093-0652, USA. ²a Jolla Bioengineering Institute, La Jolla, California 92037, USA.

Published: 29 August 2013
References
1. Wojcicka A, Bassett JH, Williams GR: Mechanisms of action of thyroid hormones in the skeleton. Biochim Biophys Acta 2013, 1832:763-772. Chen Y, Pfeifer A, Kato H, Shattil S, Boss GR, Pilz RB: Cyclic GMP and

2. Rangaswami H, Schwappacher R, Marathe N, Zhuang S, Casteel DE, Haas B,
} 
protein kinase $\mathrm{G}$ control a Src-containing mechanosome in osteoblasts. Science Signal 2010, 3:ra91.

doi:10.1186/2050-6511-14-S1-026

Cite this article as: Kalyanaraman et al:: Non-genomic thyroid hormone signaling through NO/cGMP/PKGII. BMC Pharmacology and Toxicology 2013 14(Suppl 1):O26.

Submit your next manuscript to BioMed Central and take full advantage of:

- Convenient online submission

- Thorough peer review

- No space constraints or color figure charges

- Immediate publication on acceptance

- Inclusion in PubMed, CAS, Scopus and Google Scholar

- Research which is freely available for redistribution

Submit your manuscript at www.biomedcentral.com/submit
() Biomed Central 